\title{
TIM MAUDLIN:
}

\section{Philosophy of Physics: Quantum Theory}

Princeton: Princeton University Press 2019, 250 s.

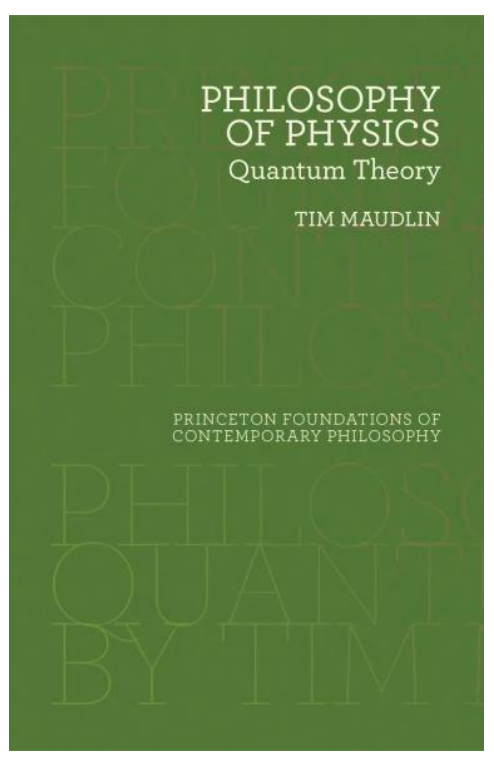

Americký filozof vedy Tim Maudlin patrí v súčasnej filozofii fyziky medzi najznámejších a najuznávanejších autorov. Viacero z jeho doterajších knižných publikácií sa vyznačuje dvoma spoločnými vlastnost'ami. Napriek zložitým témam sú pomerne ústretové aj voči čitatel'ovi, ktorý nie je špecialistom $\mathrm{v}$ danej vedeckej alebo filozofickej disciplíne, takže môžu slúžit' aj ako úvody do problematiky. Samozrejme, čitatel' začiatočník musí byt' pripravený na pomalé, pozorné čítanie a na to, že sa po ceste bude musiet' priučit' čo-to z matematického aparátu rozoberaných teórií. Druhou spoločnou črtou jeho kníh je jasnost' a rezolútnost' filozofických postojov, ktoré Maudlin obhajuje. Nezriedka pritom ide proti široko akceptovaným spôsobom uvažovania a nezdráha sa štedro rozdávat' kritiku na obe strany - smerom ku komunite fyzikov, ako aj do vlastných filozofických radov.

Ak spomenutá charakteristika platí o jeho predchádzajúcich dielach (napr. Maudlin 2011 a Maudlin 2012), na toto posledné sa hodí dvojnásobne. Jeho úvodná prezentácia kvantovej teórie si od čitatel'a žiada len nevyhnutné penzum matematiky (komplexné čísla, derivácie, matice) a patrí k tomu najlepšiemu, čo si možno $\mathrm{v}$ rámci úvodov do filozofie kvantovej fyziky prečítat', a to od čias prvého vydania dnes už klasickej knihy Davida Z. Alberta (Albert 1992). A pokial' ide o kritiku a polemiku, téma ako kvantová teória - so všetkými svojimi historickými a filozofickými peripetiami - si priam žiada razantné formulovanie vlastného stanoviska, ak autor nechce, aby sa jeho príspevok k diskusii stratil medzi desiatkami až stovkami iných interpretačných pokusov. 
Táto práca vlastne predstavuje druhý zväzok v Maudlinovej sérii Philosophy of Physics. Ten prvý sa venoval predkvantovej fyzike v širokom zábere, od Aristotela, Galileiho, Newtona až po Einsteina, pričom v centre pozornosti boli rôzne koncepcie priestoru a času s dôrazom na teóriu relativity (špeciálnu i všeobecnú). Na rozdiel od prvého, druhý zväzok nesleduje dejinnú líniu, ale vstupuje in medias res do kvantovej fyziky predstavením ôsmich kl'účových experimentov (v prvej kapitole): experiment s katódovými lúčmi (elektróny ako častice?) jednoštrbinový experiment (difrakcia: elektróny ako vlny?), dvojštrbinový experiment (aj vlny aj častice?), dvojštrbinový experiment s pozorovatel'om (záhada umocnená), Sternov-Gerlachov experiment (spin), kvantový experiment s Machovým-Zehnderovým interferometrom, myšlienkový experiment trojice Einstein, Podolsky, Rosen (EPR) a naň nadväzujúci (už reálny) experiment, testujúci takzvanú Bellovu nerovnost'. V druhej kapitole s pôvabným názvom Kvantový recept, ku ktorému sa ešte vrátime, Maudlin podáva výklad základného inštrumentária kvantovej mechaniky: vlnová funkcia, superpozícia, hermitovské operátory, kvantová previazanost' a d'alšie. V tretej kapitole sa už filozoficky pritvrdzuje, ústrednou témou je ontologický status vlnovej funkcie, kde proti sebe stoja dva nezmieritel'né prístupy: epistemický a ontický. Nasledujúce tri kapitoly sa postupne venujú trom navzájom vel'mi odlišným verziám kvantovej teórie - jednej „kolapsovej“ a dvom, ktoré „kolaps vlnovej funkcie“ nepripúšs’ajú. Vo filozofickej literatúre o kvantovej mechanike sú tieto tri „verzie“ známe aj ako tri spomedzi množstva rôznych „interpretácií“ kvantovej mechaniky - Ghirardiho-Riminiho-Weberova (GRW), de Broglieho-Bohmova (BB) a mnohosvetová -, no pri Maudlinovi musíme zaobchádzat' so slovom ,interpretácia“ trochu opatrnejšie, aby sme nezastreli ústrednú filozofickú pointu jeho knihy. Kým sa k nej dostaneme, už len doplníme, že záverečná (siedma) kapitola je venovaná relativistickým verziám spomenutých koncepcií v rámci kvantovej teórie pol’a.

Vrát'me sa teraz $\mathrm{k}$ dvom slovným spojeniam - kvantový recept a interpretácie kvantovej mechaniky -, na ktoré sme síce predtým položili prst, ale nevysvetlili sme ich relevanciu v argumentačnej línii Maudlinovej knihy. Ako sa ukazuje, tieto výrazy spolu úzko súvisia a pomocou nich sa dá osvetlit' aj Maudlinov hlavný zámer. V termíne kvantový recept je totiž pregnantne zhrnutý Maudlinov negatívny postoj k spôsobu, akým sa bežne kvantová mechanika vyučuje a ktorý bol dlhé desat'ročia posvätený takzvanou ortodoxnou, alebo Kodanskou interpretáciou (pripisovanou hlavne N. Bohrovi, W. Heisenbergovi a spol.). Maudlin nenecháva čitatel'a dlho v napätí, ale naopak, hned' v úvode diela rovno vyhlási, že historicky najuznávanejšou interpretáciou sa ani nebude zaoberat', pretože tá robí z kvantovej mechaniky iba recept na (treba uznat', vel'mi úspešné) predpovedanie 
výsledkov experimentov. To, o čo by však vo fyzike podl'a Maudlina malo íst' a to nielen u filozofov, ale aj u fyzikov samých - je teória, pod čím rozumie niečo, čo dáva jasnú odpoved’ na „dve základné otázky: čo existuje a čo to robí“ (s. xi). Inak povedané, fyzikálna teória podl'a Maudlina musí obsahovat' explicitnú ontológiu a dynamiku. Aplikované napríklad na pojem vlnovej funkcie, respektíve stavového vektora, to znamená, že fyzikálna teória kvantového sveta, ktorá si bude môct' sama seba vážit', musí jednoznačne povedat', či vlnová funkcia ako súčast' matematického formalizmu reprezentuje vo svete niečo reálne, čo presne reprezentuje a ako sa toto reprezentované vyvíja $\mathrm{v}$ čase, teda ako daný fyzikálny systém uniformným spôsobom prechádza od jedného stavu k inému. Tradičná Kodanská interpretácia ponecháva, a to musíme Maudlinovi uznat', mnohé z týchto otázok bud' otvorené, alebo ich - čo je možno ešte horšie - zahmlieva či vytesňuje neprehl'adnými formuláciami.

Z Maudlinovho pohl'adu je teda úplne oprávnené hovorit' o Kodanskej ,interpretácii“, pretože je to koncepcia, ktorá nedorástla na zrelú fyzikálnu teóriu. A preto nemá cenu bližšie sa jej venovat'. Má však význam venovat’ sa vyššie spomenutým koncepciám: GRW, BB a mnohosvetovej, pretože každá z nich predkladá ozajstnú fyzikálnu teóriu (ontológia + dynamika). To, že obraz sveta, ktorý vykresl'ujú tieto tri verzie kvantovej teórie, je radikálne odlišný, je len voda na mlyn hlbšej filozofickej reflexii a príležitost' pre starostlivé zvažovanie argumentov pre a proti. Sám Maudlin sa prikláňa na stranu bohmovskej mechaniky.

Maudlinove poznámky o „fyzikálnej teórii“ v kontexte kvantovej fyziky môžeme do značnej miery vnímat' ako št'uchnutie pod rebro, adresované tým profesionálnym fyzikom, ktorí dlhý čas väčšinovo brali kodanskú verziu ako kanonickú, a ked' sa už inak nedalo, hl'adali pre svoje fyzikálne svedomie kvázi filozofické útočisko v nejakom type pragmatického či inštrumentalistického postoja (pričom nezriedka sa kodanské stanovisko zlievalo v jedno s čistým inštrumentalizmom). Ako však už bolo spomenuté na začiatku, Maudlin má niečo schované aj pre filozofov. Podobne ako sa v celom texte (okrem úvodu) stráni slova Copenhagen, rovnako to chce dodržat' aj vo vzt’ahu k čisto filozofickej dvojici termínov realizmus a antirealizmus. Jeho rozhodnutie vychádza zo zmätkov, ktoré táto terminologická dvojica podl’a jeho názoru napáchala vo filozofickej literatúre. V prvom rade poukazuje na nešt’astné pripisovanie adjektív realistický a antirealistický jednotlivým vedeckým teóriám, zatial' čo správne by sa mali pod realizmom či antirealizmom rozumiet' skôr osobné postoje k príslušným teóriám. S tým by sa dalo celkom dobre súhlasit', najmä ak sme s Maudlinom zajedno v chápaní slova „teória“. Trochu menej sa však už dá rozumiet' tomu, prečo Maudlin chápe rozlíšenie medzi realizmom a antirealizmom ako niečo, čo patrí čisto len do epistemológie, a teda nemá nič spoločné s tým, čo je predmetom tejto jeho knihy. Ked' napríklad Maudlin v tretej kapitole 
obhajuje takzvané ontické chápanie vlnovej funkcie $\psi$, teda stanovisko, že $\psi$ reprezentuje nejakú reálnu črtu skúmaného fyzikálneho systému, proti rôznym typom epistemického chápania, zdá sa nám, že Maudlin sa tu pohybuje práve v tých vodách, kde rozlíšenie medzi realistickými a antirealistickými postojmi tradične bolo, a aj je celkom prirodzené. Mieru averzie k tejto terminológii u Maudlina možno dobre ocenit' v pasáži, v ktorej doslova hovorí, že keby to bolo čisto na ňom, spomínanú dvojicu izmov by v akýchkol’vek diskusiách o základoch fyziky celkom zakázal.

Tretia kapitola obsahuje aj jednu zaujímavú úvahu o ontologickej povahe kvantového stavu (chápaného ako predmetný korelát vlnovej funkcie). Zrejme, na prekvapenie mnohých, Maudlin túto záhadu rieši takpovediac jej uzákonením. Pýtat' sa, $\mathrm{k}$ akej ontologickej kategórii aristotelovského či iného typu kvantový stav patrí, je podl’a Maudlina neužitočná a neopodstatnená otázka. Namiesto toho nám odporúča zmierit' sa s tým, že prosto prijmeme do svojej „tabul'ky kategórií“ jednu novú kategóriu, a to kategóriu kvantového stavu (s. 89). Uznáva síce, že týmto „trikom“ sme sa nič nové nedozvedeli, ale stratu nádeje na porozumenie kvantovému stavu cez prizmu niečoho „pre nás známejšieho“ sa usiluje kompenzovat’ presmerovaním našej pozornosti na zaujímavejšie a konštruktívnejšie otázky ako tie, či existuje iba jeden kvantový stav (univerza ako celku), alebo môžu existovat' viaceré; prečo má kvantový stav práve takú matematickú formu, akú má; ktoré matematické charakteristiky (features) vlnovej funkcie zodpovedajú fyzikálnym charakteristikám kvantového stavu a pod. Asi možno súhlasit's tým, že tento typ otázok sa javí ako produktívnejší, no inštalovanie novej ontologickej kategórie kvantového stavu zanecháva prinajmenšom pocit nespokojnosti. Tak to je zrejme vždy pri fundamentálnych otázkach, kde je na výber len medzi tým, že neznámu entitu vtlačíme do nejakej známej priehradky, voči ktorej sa výrazne vzpiera, alebo ju ponecháme osve a bez deformácie, no zároveň bez prepojenia so sférou známeho. Horšie by bolo, keby sa ukázalo, že napríklad na otázku, prečo má kvantový stav práve danú matematickú formu, nemožno rozumne odpovedat', pokial' lepšie nevyjasníme práve kategoriálne začlenenie kvantového stavu.

V poslednej kapitole, ktorá je venovaná relativistickej kvantovej teórii pol’a sa vel'mi výrazne prejavuje Maudlinova inklinácia k bohmovskej teórii. Sú tu síce spomenuté a prístupným spôsobom vysvetlené všetky základné problémy, ktorým čelí každý pokus o filozofickú interpretáciu ontologických záväzkov súčasných kvantových teórií pol’a, no spomedzi rôznych návrhov riešení autor podrobnejšie predstavuje len bohmovsky orientovanú Bellovu teóriu. Okrem rozsahových obmedzení sa však tento krok dá do istej miery ospravedlnit' tým, že autor chce takýmto spôsobom aj v závere knihy zvýraznit’ kontrast medzi skutočnou teóriou a verziami kvantového receptu, ktoré nachádza aj v štandardných učebniciach kvantovej teórie pol'a. 
V Maudlinovej knihe sa tu a tam nájdu dôvody na nesúhlas. Niektorí autori na poli filozofie fyziky môžu oprávnene pocit’ovat' nespokojnost', že ich tézy a argumenty neboli vzaté do úvahy, alebo boli vybavené prirýchlo. Je však isté, že dokonca aj títo poslední by uznali, že najnovšia Maudlinova kniha po mnohých iných stránkach dokonale splnila očakávania: pre tých, čo ešte len vstupujú na jej tematické teritórium, je didakticky výborne zvládnutá, a pre špecialistov je prinajmenšom vel’mi zaujímavá a provokatívna.

\section{Literatúra}

ALBERT, D. Z. (1992): Quantum Mechanics and Experience. Cambridge: Harvard University Press.

MAUDLIN, T. (2007): The Metaphysics within Physics. Oxford: Oxford University Press.

MAUDLIN, T. (2011): Quantum Non-Locality and Relativity. Malden: Wiley-Blackwell. First edition 1994.

MAUDLIN, T. (2012): Philosophy of Physics: Space and Time. Princeton - Oxford: Princeton University Press.

Recenzia vznikla ako súčast' riešenia grantového projektu VEGA, Realizmus a antirealizmus $v$ súčasnej filozofii vedy, č. 1/0258/2019.

Róbert Maco

Univerzita Komenského v Bratislave

Filozofická fakulta

Katedra filozofie a dejín filozofie

Gondova 2

81102 Bratislava 1

Slovenská republika

e-mail: robert.maco@uniba.sk

ORCID ID: https://orcid.org/0000-0001-5061-9344 